\title{
Organizational Learning and Operational Performance of Water and Sanitation Corporation (WASAC), Rwanda
}

\section{Louis MUHIGIRWA ${ }^{1}$, Francis MWANGI ${ }^{2}$ and Alice KITUYI ${ }^{3}$}

\author{
${ }^{1,2,3}$ School of Business and Economics, Mount Kenya University, \\ Kigali, Rwanda
}

\begin{abstract}
This study investigated relationship between organizational learning and operational performance of Water and Sanitation Corporation. In Rwanda. Specifically, the study examined the influence of knowledge acquisition, information distribution, and organizational memory on organizational performance. The study was correlational by relating predicator (operational performance) with its criteria variables (organizational learning). It was conducted on a sample size of 239 respondents. The study used structured questionnaires and interview guides and analyzed data using SPSS version 23. A multiple regression analysis indicated that that knowledge acquisition was positive and significantly related to operational performance $(\mathrm{B}=0.168, \mathrm{p}$ value $=0.002)$. The study indicated that information distribution was also positively and significantly related to operational performance $(\mathrm{B}=0.257$, $\mathrm{p}$ value $=0.001)$. This implies that an improvement in information distribution by one unit leads to an increase in business operations' performance by 0.257 units. Information distribution positively correlated to operational performance $(\mathrm{B}=0.372, \mathrm{p}$ value $=0.000)$. The study recommended that Water and Sanitation Corporation should ensure that employees are empowered on methods of retrieving data for different purposes as per their needs, in order to enhance the decision-making process.

Keywords: Organizational Learning, Operational Performance, Customer Satisfaction, Information Distribution, Organizational Memory
\end{abstract}

\section{Introduction}

The dynamism of the business landscape brings both disruptive as well as constructive changes to an organization. It is agreed that learning is key to this process (Yasir, 2016). Dai, Duserick, and Huang (2007) believed that new management technique is the interaction between organizational learning and corporate resources. Majila (2012) reiterates that strategic management enables the organization to learn different ways of mutual activities which improves effectiveness. Other opponents of organizational learning show a relationship with monetary and non-monetary performance, physical and non-physical joint efforts in the process of knowledge acquisition (Majila, 2012; Wafula, et al., 2016).

MINIFRA (2017) observes that Rwanda is committed to meeting the all-inclusive access to water and sanitation by 2020 . The water and sanitation policy was adopted in 2010 to fasten the access to clean water supply and sanitation administrations and Water and Sanitation Corporation (WASAC) was established to take care of water and sanitation services. The company was expected to make improvements from the previous operations that were marred by wasteful and inefficient operations, weak institutional management focus, and poor planning and investments to an established consumer-centric service that was not only sustainable, but also universal (WASAC,2019). The experience in Rwandan public sector shows that there is little organizational learning. Knowledge acquisition is rarely used. Mentorship was inadequate for incoming employees who end up working without basic skills on how to interact with systems in the organizations. This led to insecure workers, over reliance of outsourcing from oracle system experts, which is a possible challenge to project sustainability. Monitoring and Evaluation reports were not used to enrich knowledge neither are organizations researching knowledge on their institutions so as to increase on organization memory (Umugwaneza \& Kule, 2016). The study sought to investigate the relationship between organizational learning and operational performance of WASAC in Rwanda.

The research objectives were:

i. To examine the effect of knowledge acquisition on the operational performance of WASAC. 
ii. To assess the impact of information distribution on the operational performance of WASAC

iii To investigate the effect of organizational memory on the operational performance of WASAC.

iv. To determine the operational performance level of WASAC

v. To evaluate the relationship between organizational learning and the operational performance of WASAC.

\section{Review of Literature}

Hagen (2012) specified that positive outcomes incorporate worker satisfaction and execution; firm duty; decrease in turnover expectation; improvement of performance; upgraded venture the executives' results; consumer loyalty; and expanded execution of sales. A study by Bakker and Leiter (2010) and Hagen (2012) revealed a positive relationship between managers and work engagement. Schaufeli, et al. (2012) did not find the link between coaching and explicit meanings of work commitment in existing literature. A cross section analysis of organizations by Ellinger, et al. (2011) indicated that manager's coaching behaviors had a positive influence on employee's view of their work execution and quality of service. In a similar study by Kim, Egan, Kim, and Kim (2013), findings suggested that workers who got training had enhanced clarity in regard to their roles, were highly happy with their employment, and were focused on the firm.

Tagbotor, et al. (2015) suggested that the electronic recording system allowed employees to finish and present their data in time. Thus, the study strongly recommended training, supervision, and control on records and the board aptitudes for all employees in the association so as to improve execution. In an attempt to study how Organizational Learning (OL) influences the presentation of organizations in the food industry in Kenya, Ouma (2016) used the Knowledge Based Theory on a sample of 71 firms. The study concluded that organizational learning in firms should include all dimensions because together they provide a combined effect on operational performance.

Dermol (2013) approached organizational learning by implementing four associated constructs identified with the procedures of learning and information creation, and operational execution. The researcher applied structural equation modelling to conclude the existence of positive connections between the development and obtaining of data, creation of knowledge, and changes in behavior and cognition. All these constructs had significant impacts on operational performance. A beneficial outcome of organizational learning on a firm's performance was established by Smith (2001). Calantone, et al. (2002) linked organizational learning with knowledge creation, which was fundamental in enabling firms in responding to diverse changes in, buyer needs, and industry changes. Likewise, studies by Farrell (1999) identified organizational learning with positive and promising yields in organizations.

Organizational learning process is a sequence of three phases: Knowledge acquisition, information distribution and organizational memory. When measuring the above terms, we asked respondents about their degree of dis/agreement about changes from 2015 to 2019 in selected items. The modern business is characterized by increased internal Organizational Efficiency, employee Performance and increased customer Satisfaction. When measuring the above terms, we asked respondents about their degree of dis/agreement about changes from 2015 to 2019 in selected items.

\section{Materials and Methods}

The study used a descriptive survey with the aim of presenting an understanding of how organizational learning affects firm performance. Gay (1992) defines a descriptive study design as one involving data collection with the point of addressing examination questions concerning the subject of inquiry. The target population was 593 (201 branches employees, 179 water treatment plant employees, 74 managers, and 139 employees from the head office. Slovin's formula was used to calculate the sample size. Eq (1):

$$
\begin{aligned}
& n=\frac{N}{1+N(e)^{2}} \\
& \text { Thus, } \mathrm{n}=\frac{\mathrm{N}}{1+\mathrm{Ne}^{2}}=\frac{593}{1+593(0.05)^{2}}=239
\end{aligned}
$$

From the total population of each stratum, a sample size of 81 Branch employees was selected, 72 employees from Water treatment plants employees, 56 employees from head office employees, and 30 managers. This ensured a randomized sampling that gave every participant an equal chance. Analysis of data involved the procedure of organizing, synthesizing, and searching for significant patterns in the crude information gathered. The information was coded to generate themes which would already been formulated. Data was entered into the SPSS 25.0 for analysis. To establish the relationships under investigation, each concept in the independent variable was correlated with the operational performance constructs and Pearson's correlation coefficient determined. Regression analyses summed all the dependent variable constructs and regressed against the independent variable. The $R$ (regression coefficient) was utilized to explain the nature and strength of the relationship. A model was provided depending on the outcome of the regression that was further used to quantify the relationship under investigation. 


\section{Results and Discussion}

4.1. Influence of Knowledge Acquisition on Operational Performance
The study's first research objective aimed at examining how knowledge acquisition influenced the operational performance of WASAC.

Table 4.1 Opinion Regarding the Extent to which Knowledge Acquisition affects Operational Performance in WASAC

\begin{tabular}{lcc}
\hline Responses & Frequency & Percent \\
\hline No Extent & 8 & 3.3 \\
Little Extent & 16 & 6.7 \\
Moderate Extent & 11 & 4.6 \\
A Great Extent & 134 & 56.1 \\
A Very Great Extent & 70 & 29.3 \\
Total & 239 & 100.0 \\
\hline
\end{tabular}

Source: Primary Data, 2020

Table 4.1 reveals that, $3.3 \%$ of the respondents suggested that the effect of knowledge acquisition to the operational performance of WASAC was to no extent, $6.7 \%$ suggested that the effect was to little extent, $4.6 \%$ suggested that the effect was to moderate extent, $56.1 \%$ suggested that the effect was to a great extent, and $29.3 \%$ suggested that the effect was to a very great extent.

\subsection{Influence of Information Distribution on Operational Performance}

The study's second research objective was to assess how information distribution influenced the operational performance of WASAC.

Table 4.2 Opinions regarding the extent to which Information Distribution affects Operational Performance in WASAC

\begin{tabular}{lcc}
\hline Responses & Frequency & Percent \\
\hline No Extent & 17 & 7.1 \\
Little Extent & 18 & 7.5 \\
Moderate Extent & 32 & 13.4 \\
A Great Extent & 74 & 31.0 \\
A Very Great Extent & 98 & 41.0 \\
Total & 239 & 100.0 \\
\hline
\end{tabular}

Source: Primary Data, 2020

The study asserts that $7.1 \%$ of the respondents suggested that information distribution affected the operational performance in WASAC was to no extent, $7.5 \%$ suggested that the effect was to little extent, $13.4 \%$ suggested that the effect was to moderate extent, $31 \%$ suggested that the effect was to a great extent, and $41 \%$ suggested that the effect was to a very great extent.

\subsection{Influence of Organizational Memory on Operational Performance}

The third research objective was to investigate the influence of organizational memory on the operational performance of WASAC.

Table 4.3 Opinions regarding the extent to which Organizational Memory affects Operational Performance in WASAC

\begin{tabular}{lcc}
\hline Responses & Frequency & Percent \\
\hline No Extent & 12 & 5.0 \\
Little Extent & 23 & 9.6 \\
Moderate Extent & 94 & 39.3 \\
A Great Extent & 38 & 15.9 \\
A Very Great Extent & 72 & 30.1 \\
Total & 239 & 100.0 \\
\hline
\end{tabular}

Source: Primary Data, 2020 
As indicated in Table 4.3 , 5\% of the respondents suggested that the effect of organizational memory on operational performance in WASAC was to no extent, 9.6\% suggested that the effect was to little extent, $39.3 \%$ suggested that the effect was to moderate extent, $15.9 \%$ suggested that the effect was to a great extent, and $30.1 \%$ suggested that the effect was to a very great extent.

\subsection{Operational Performance Level of WASAC}

The study sought to determine the operational performance level of WASAC.

Table 4. 4 Operational Performance Level of WASAC

26-50\% $51-76 \% \quad$ Above $77 \% \quad$ Total

Performance Metric

Less than $25 \%$

\begin{tabular}{lccccc}
\hline Internal Organizational Efficiency & 3.8 & 12.1 & 37.2 & 46.9 & 100.0 \\
Employee Performance & 8.4 & 13.0 & 11.7 & 66.9 & 100.0 \\
Customer Satisfaction & 20.9 & 28.5 & 27.2 & 23.4 & 100.0 \\
\hline
\end{tabular}

Source: Primary Data, 2020

As indicated in Table 4.4, the performance levels of less than $25 \%$ were low, $26-50 \%$ were fair, $51-76 \%$ were high, and above $77 \%$ were very high. It was indicated that the operational performance levels for internal organizational efficiency and employee performance were very high as both had high scores (above 77\%). For customer satisfaction, findings from the study revealed that the performance level was fair as it recorded percentages ranging from $20.9 \%$ to $28.5 \%$.

\subsection{Correlation Analysis}

Pearson correlation analysis and regression analyses were used to find the relationship between the variables. All the correlations were statistically significant given that the $\mathrm{p}$ values were $<0.05$.

Table 4. 5 Correlation Analysis

\begin{tabular}{llccc}
\hline & & $\begin{array}{c}\text { Internal Organizational } \\
\text { efficiency }\end{array}$ & $\begin{array}{c}\text { Employee } \\
\text { Performance }\end{array}$ & $\begin{array}{c}\text { Customer } \\
\text { Satisfaction }\end{array}$ \\
\hline Knowledge & Pearson & $.158^{* *}$ & $.413^{* *}$ & $.710^{*}$ \\
Acquisition & Correlation & .015 & .037 & .024 \\
& Sig. (2-tailed) & 239 & 239 & 239 \\
\hline Information & $\mathrm{N}$ & $.705^{*}$ & $.530^{*}$ & $.271^{*}$ \\
Distribution & Pearson & & & .021 \\
& Correlation & .025 & .041 & 239 \\
\hline Organizational & Sig. (2-tailed) & 239 & 239 & $.235^{* * *}$ \\
Memory & $\mathrm{N}$ & $.323^{*}$ & .081 & .001 \\
& Pearson & & & 239 \\
& Correlation & .023 & .214 & 239 \\
\hline
\end{tabular}

Source: Primary Data, 2020

There were positive correlation between knowledge acquisition and internal organizational efficiency (r.158*, p.015), knowledge acquisition and employee performance (r.413*, p.037), knowledge acquisition and customer satisfaction (r.714, p.024). There were positive correlation between information distribution and internal organizational efficiency (r.705*, p.025), information distribution and employee performance (r.530*, p.041), information distribution and customer satisfaction (r.271, p.021). There were correlations between organizational memory and internal organizational efficiency $\left(r .323^{*}, \mathrm{p} .023\right)$, between organization memory and customer satisfaction customer satisfaction (r. 235**, p .001). All these correlations were statistically significant given that the $\mathrm{p}$ values were $<0.05$ and $<0.01$. The implication was that high levels of knowledge acquisition, information distribution and organization 
memory within WASAC would significantly enhance internal organizational efficiency and customer satisfaction. Contrary, the correlations between organizational memory and employee performance was insignificant (r. 081, p .214) as the $\mathrm{p}$ value was $>0.05$, and hence the study could not determine how organizational memory affected employee performance. A simple multiple regression model was used to test for the relationship between the independent variables on the dependent variable, regression analysis was employed.

Table 4.6 Coefficients between Organizational Memory, Information Distribution, Knowledge Acquisition and Operational Performance of WASAC

\begin{tabular}{|c|c|c|c|c|c|c|}
\hline \multirow[t]{3}{*}{ Model } & & \multicolumn{2}{|c|}{ Unstandardized } & Standardized & $\mathbf{t}$ & Sig. \\
\hline & & \multicolumn{2}{|c|}{ Coefficients } & \multirow{2}{*}{$\begin{array}{c}\text { Coefficients } \\
\text { Beta }\end{array}$} & & \\
\hline & & B & Std. Error & & & \\
\hline \multirow{4}{*}{1} & (Constant) & .423 & .162 & & 2.606 & .010 \\
\hline & Knowledge Acquisition & .174 & .056 & .168 & 3.082 & .002 \\
\hline & Information Distribution & .247 & .070 & .257 & 3.516 & .001 \\
\hline & Organizational Memory & .327 & .070 & .372 & 4.640 & .000 \\
\hline
\end{tabular}

a. Dependent Variable: Operational Performance

The regression equation used to link the dependent and independent variable was as follows;

$\mathrm{Y}=\mathrm{b}_{0}+\mathrm{b}_{1} \mathrm{X}_{1}+\mathrm{b}_{2} \mathrm{X}_{2}+\mathrm{b}_{3} \mathrm{X}_{3}+\mathrm{e}$

$\mathrm{Y}=0.423+0.168 \mathrm{X}_{1}+0.257 \mathrm{X}_{2}+0.372 \mathrm{X}_{3}+\boldsymbol{\varepsilon}$ Where $\mathrm{y}=$ operational performance

$\mathrm{X}=$ independent variables $\mathrm{X} 1$

= Knowledge Acquisition

$\mathrm{X} 2$ = Information Distribution

X3 = Organizational memory

$\mathrm{e}=$ Error term

Results indicate that knowledge acquisition was positively correlated with operational performance $(\mathrm{B}=0.168, \mathrm{p}$ value $=0.002)$. This implies that an improvement in knowledge acquisition by one unit leads to an increase operational performance by 0.168 units. The study indicated that information distribution was positively correlated to operational performance $(\mathrm{B}=0.257, \mathrm{p}$ value $=0.001)$. This implies that an increase in information distribution by one unit leads to an increase in operational performance by 0.257 units. Lastly the study indicated that information distribution positively correlated with operational performance $(\mathrm{B}=0.372, \mathrm{p}$ value $=0.000)$. This implies that an improvement in information by one unit leads to an increase operational performance by 0.372 units.

\subsection{Discussion}

The findings were consistent with empirical evidence linking employee training with high levels of employee performance (Yeganeh \& Kolb, 2009). Frequent training and workshops expose employees to external sources of information through which they gain new information applicable to the duties. Despite the role of company reports, results suggested that a small fraction of WASAC's employees got their relevant knowledge from reports.

Hence, results were in line with Tagbotor, et al. (2015) who linked electronic recording system with reduced errors, and improve operational performance. Findings were consistent with Dermol (2013) who linked organizational memory with interpretation of information and creation of knowledge.

This study concurs with Ouma (2016) who established positive relationships between organizational learning and operational performance and. It did not contract, Bakker and Leiter (2010) and Hagen (2012) who revealed the existence of positive relationships between managers as coach and work engagement.

\section{Conclusions}

The study concluded that knowledge from reports is pertinent in transforming WASAC, despite challenges on the how reports are used. Unfortunately, WASAC's managers and workers were not fully empowered to explore data. Results deduced that WASAC's knowledge acquisition affected its operational performance to a great extent.

Findings suggested positive correlations between knowledge acquisition and operational performance. There were positive correlations between information distribution and operational performance. There were positive correlations between organizational memory and operational performance. The correlations between organizational memory and employee performance 
was insignificant correlated. A regression analysis suggested that employee performance was not significant in predicting the influence of organizational learning on employee performance. Hence, WASAC needs to develop HR measures aimed at assessing factors determining employee performance. Public institutions may differ in terms of knowledge needs and levels of competency. Results could not be generalized. Future studies should concentrate on conducting similar studies using different case studies in the private and public sectors in order to allow for comparison and generalization.

\section{Acknowledgments}

I wish to acknowledge Dr. Alice Kituyi Kwake and Francis Mwangi for her contribution to this work from the beginning up to it's the completion. I also wish to extend my acknowledgement to the Mount Kenya University, WASAC authorities for their support and collaborative in term of data collection.

\section{Reference}

[1] Bakker, A., \& Leiter, M. (2010). Work engagement: A handbook of essential theory and research. New York: Psychology Press

[2] Calantone, R. J., Cavusgil, S. T., \& Yushan, Z. (2002). Learning orientation, firm innovation capability, and firm performance. Industrial Marketing Management, 31(6), 515-524.

[3] Dai, Z., Duserick, F., \& Huang, W. V. (2007). Strategic Implementation of Organizational Learning: An Empirical Study. World, 5, 17.

[4] Dermol, V. (2013). Relationship between learning, knowledge creation and organisational performance. Annals of the Alexandru Ioan Cuza University-Economics, 60(1), 79-93. https://doi.org/10.2478/aicue-2013-0008

[5] Ellinger, A. D., Ellinger, A. E., Bachrach, D., \& Al, E. (2011). Organizational investments in social capital, managerial coaching, and employee work-related performance. Management Learning, 42(1), 67-85.

[6] Farrell, M.. (1999). Antecedents and consequences of a learning orientation. Marketing Bulletin, 10, 38-51.

[7] Gay, L. R. (1992). Education Research Competencies for Analysis and Application: London. Charles E. Miton Keynes Philadelphia Company.

[8] Hagen, M. (2012). Managerial coaching: A review of the literature. Performance Improvement Quarterl, 24(1), 17-39.
[9] Huber, G. P. (1991). Organisational learning: The contributing processes and the literatures. Organisation Science, 2, 88-115.

[10] Kim, S., Egan, T., Kim, W., \& Kim, J. (2013). The impact of managerial coaching behaviour in employee work-related reactions. Journal of Business Psychology, 28, 31-330.

[11] Majila, V. T. (2012). Organizational Learning in the Public Sector: a study with reference to the Eastern Cape Department of Human Settlements. Uniersity of Stellenbosch.

[12]MINIFRA. (2017). Water and Sanitation 2017/2017 Backward-looking joint sector review report. Kigali. Retrieved from http://www.mininfra.gov.rw/fileadmin/user_upl oad/infos/WATSAN_2016-2017_Backward_Looking_joint_sector_Review_Report.pdf

[13] Ouma, R. (2016). Effect of Organizational Learning on Operational performance of Food Manufacturing Firms in Nairobi County, Kenya. European Journal of Business Management, 8(30), 54-61.

[14] Salanova, M., Schaufeli, W., Bakker, A., \& González-Romá, V. (2012). The measurement of engagement and burnout: A confirmative analytic approach. Journal of Happiness Studies, 3, 71-92.

[15] Smith, M. K. (2001). Experiential learning. In Encyclopedia of informal education (pp. 1-15). Retrieved from http://www.infed.org/bexplrn.htm

[16] Tagbotor, D. P., Adzido, R. Y., \& Agbanu, P. G. (2015). Analysis of Records Management and Operational performance. International Journal of Academic Research in Accounting, Finance and Management Sciences, 5(2), 1-16. Retrieved from http://hrmars.com/hrmars_papers/Article_01_An alysis_of_Records_Management_and_Organizat ional_Performance.pdf

[17] Umugwaneza, A., \& Kule, J. W. (2016). Role of monitoring and evaluation on project sustainability in Rwanda. A case study of Electricity Access Scale-Up And Sector-Wide Approach Development Project (EASSDP). European Journal of Business and Social Sciences 5(07), 159-177. Retrieved from http://www.ejbss.com/recent.aspx-/

[18] Wafula, R. O., Nyakenyanya, N. A., Nyamboga, C. M., \& Okello, G. (2016). Knowledge Management Practices and Operational performance in Selected Campuses of Kisii University, Kenya. SRELS Journal of Information Management, 53(5), 349-358. 
[19]WASAC. (2019). History. Retrieved May 27 2019, from https://wasac.rw/index.php/aboutus/history

[20] Yasir, A. R. (2016). The Impact of Organizational Learning on Firm's Perceived
Financial Performance: Taking the Role of Leadership as Moderator. National University of Modern Languages, Islamabad

[21] Yeganeh, B., \& Kolb, D. (2009). Mindfulness and experiential learning. OD Practitioner, 41(3). 